\title{
Quality of mini tomatoes harvested at two maturity stages and kept chilled in three packages
}

\author{
Vanessa C Caron ${ }^{1}$; Magda A Tessmer ${ }^{2}$; Simone C Mello; ${ }^{1}$ Angelo P Jacomino ${ }^{1}$ \\ ${ }^{1}$ USP-ESALQ, Depto. Prod. Vegetal, C. Postal 9, 13418-900 Piracicaba-SP; 2USP-ESALQ, Depto. Ciências Biológicas; vanessac@usp. \\ br; mtessmer@usp.br; scmello@usp.br; jacomino@usp.br
}

\begin{abstract}
The economic importance of small tomato fruits has been increased considerably due to the significant levels of lycopene and sugars. However, to achieve these compounds, the harvest is limited to a ripening stage demanded by consumers, which could reduce this marked period. Harvesting at an early stage and use of conservation techniques are desirable to amplify the marketing period. The aim of this study was to evaluate the quality of small tomato fruits, Sweet Grape cultivar, harvested at two stages of ripening (light red and red), kept in three types of package (perforated PET, PEBD $30 \mu$ and Vegetal Pack $18 \mu$ ) at a temperature of $20 \pm 1^{\circ} \mathrm{C}$ and a relative humidity $(\mathrm{RH})$ of $85 \pm 5 \%$ during 20 days. During this period, gas composition inside the packaging $\left(\mathrm{O}_{2}\right.$, $\mathrm{CO}_{2}$ and ethylene), peel color, fresh mass loss, soluble solids content (SS), titratable acidity (TA), SS/TA and ascorbic acid levels were evaluated every 5 days. The lycopene content was determined at the beginning and the end of conservation. The experimental design was completely randomized in a split plot with four replications. Mass loss, peel color and gas composition were affected by both stage of harvest and package. The total SS/TA increased 4.74 during the conservation for two stages, regardless of package. The light red fruits reached after 20 days of conservation, mean levels of lycopene of $16.47 \mathrm{mg}_{100 \mathrm{~g}^{-1} \text { and }}$ $\mathrm{SS} / \mathrm{TA}$ of 18.43; on the other hand the red fruits achieved $15.30 \mathrm{mg} 100$ $\mathrm{g}^{-1}$ of lycopene and 16.80 of SS/TA. There was a mean increase of 8.4 $\mathrm{mg} 100 \mathrm{~g}^{-1}$ of lycopene in light red fruits, while in red fruits, the increase

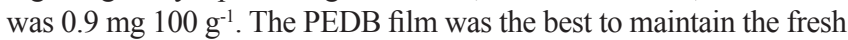
mass and peel color, therefore it was indicated for the maintenance of these attributes. The Vegetal Pack film showed no advantage in relation to the PET perforated packaging.
\end{abstract}

Keywords: Solanum lycopersicum, maturity stage, conservation, modified atmosphere.

\section{RESUMO}

Qualidade de mini tomates colhidos em dois estádios de maturação e conservados refrigerados em três embalagens

A importância econômica do mini tomate tem crescido consideravelmente, sendo um dos motivos os teores significativos de licopeno e de açúcares redutores. Para alcançar estes atributos, a colheita é realizada no ponto de consumo, o que reduz sua vida útil. Colheita em estádio precoce e uso de técnicas de conservação são desejáveis para ampliar o período de comercialização. Dentro deste contexto, o objetivo deste trabalho foi avaliar a qualidade de mini tomates, cultivar Sweet Grape, colhidos em dois estádios de maturação (vermelho claro e vermelho), mantidos em três embalagens (PET perfurada, PEBD $30 \mu$ e Vegetal Pack $18 \mu$ ) a $20 \pm 1^{\circ} \mathrm{C}$ e $85 \pm 5 \%$ de UR por 20 dias. Durante este período foram avaliadas a cada 5 dias a composição gasosa no interior das embalagens $\left(\mathrm{O}_{2}, \mathrm{CO}_{2}\right.$ e etileno $)$, a coloração da casca, a perda de massa fresca, o teor de sólidos solúveis (SS), a acidez total (AT) e o teor de ácido ascórbico. O teor de licopeno foi determinado no início e no final da conservação. O delineamento experimental foi inteiramente casualizado, em parcela subdividida, com quatro repetições. A perda de massa, a coloração da casca e a composição gasosa foram afetadas tanto pelos estádios de maturação quanto pelas embalagens. A relação SS/AT aumentou 4,74 durante a conservação, independente do tipo de embalagem. Os frutos em estádio vermelho claro alcançaram, aos 20 dias de conservação, teores médios de licopeno de 16,47 mg 100 $\mathrm{g}^{-1}$ e relação SS/AT de 18,43, enquanto os frutos em estádio vermelho apresentaram 15,30 mg $100 \mathrm{~g}^{-1}$ de licopeno e 16,80 de SS/AT. Houve

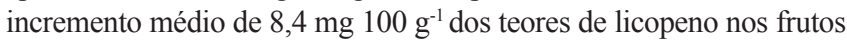
vermelho claro, enquanto que nos vermelhos, o aumento foi de $0,9 \mathrm{mg}$ $100 \mathrm{~g}^{-1}$. O filme PEBD foi o que melhor manteve a massa fresca e a coloração da casca, por isso foi o indicado para a manutenção destes atributos. O filme Vegetal Pack não apresentou vantagem em relação à embalagem PET perfurada.

Palavras-chave: Solanum lycopersicum, estádio de maturação, conservação, atmosfera modificada.

\section{(Recebido para publicação em 29 de fevereiro de 2012; aceito em 9 de maio de 2013) (Received on February 29, 2012; accepted on May 9, 2013)}

\begin{abstract}
A nnual tomato consumption is the highest of all the vegetables, reaching $5 \mathrm{~kg}$ per capita in Brazil in 2008-2009 (IBGE, 2008-2009). The annual increase in mini tomato cropping, as with all the mini vegetables, is estimated at 15 to $20 \%$ (Junqueira et al., 2011). This group of tomatoes stands out as a product with high aggregated value and its market price is 20 to $30 \%$ higher
\end{abstract}

than traditional tomatoes (Junqueira et al., 2011). Tomatoes are attractive for consumption due to a low acid index and high reducing sugars content (Picha, 1986) that considerably affect the fruit flavor (Beckles, 2012), as well as great culinary versatility, dark red peel and pulp coloring, small fruit size (10-20 g) and smooth, thin peel (Junqueira et al., 2011).
The tomato fruit is the main source of lycopene in the human diet along with its derivatives (Carvalho et al., 2005), because they have strong antioxidant action that helps prevent degenerative and heart diseases and certain types of cancer. The mini tomato can further present higher levels of carotene and antioxidant activity than conventional tomatoes (Raffo et al., 2002). These 
properties are intensified when the fruits are at the most advanced ripeness stage, ideal for consumption (Kader, 2008). For this, the ripeness stage of the tomato at the time of harvesting and also the control of pre-and post-harvest factors are essential to ensure the quality demanded by the consumers (Moura et al., 1999; Beckles, 2012). The ripeness stage recommended for harvesting is when the peel of the mini tomato presents more than $90 \%$ red coloring (USDA, 1991). However, as the tomato is a climacteric fruit, it is probable that harvesting at the light red stage (60 to $90 \%$ red colored peel) would give the productive and commercial sectors greater flexibility for its management.

Storing tomatoes post-harvest depends on various pre-harvest factors and using procedures that maintain their nutritional and organoleptic quality (Kader, 2008). One of the most successful techniques is using modified atmosphere, with plastic films, that represents a barrier to the exit of water vapor and gas exchanges and reduces the respiratory activity of the fruit (Kader et al., 1989). The permeability of the films to gases allows the carbon dioxide concentration resulting from the fruit respiration increase while the oxygen concentration decreases from its consumption in the respiratory process. Thus the fruit metabolism goes through biochemical and physiological alterations, leading to a considerable increase in its life after harvest (Day, 2002). The atmospheric composition inside the package depends on the permeability characteristics of the plastic film material, on the number of fruits packed and the storage temperature (Gorris \& Peppelenbos, 1992; Mosca et al., 1999). Using packaging can favor fruit conservation, ensuring the maintenance of characteristics such as color, aroma, flavor and firmness.

Several studies have been carried out using plastic films associated or not with other post-harvest storage technologies in tomatoes, where use of films based on polyethylene and polypropylene has been emphasized to maintain the quality attributes related to the fresh mass and peel coloring (Vanndy et al., 2008; Sabir \& Agar, 2011; Akbudak et al., 2012).
Currently the perforated PET type of packaging is used for mini tomato that has no barrier to the carbon dioxide and oxygen gases. Other films, such as low-density polyethylene (PEBD) and Vegetable Pack are barriers against gases and thus alter the internal composition of the packages. The $30 \mu$ thick PEBD film has a permeability rate to $\mathrm{O}_{2}$ of $7,489 \mathrm{~mL}$ (CNT) $\mathrm{m}^{-2}$ day $^{-1}$ and to $\mathrm{CO}_{2}$ of 27,900 $\mathrm{mL}$ (CNTP) $\mathrm{m}^{-2}$ day $^{-1}$ (Caron, 2009). Vegetable Pack, defined as a modifying self-control atmosphere membrane with zeolite technology (gas absorber), at 18 $\mu$ thickness, permits a permeability to oxygen of 9,185 mL (CNTP) $\mathrm{m}^{-2}$ day $^{-1}$ and to $\mathrm{CO}_{2}$ of $41,100 \mathrm{~mL}(\mathrm{CNT}) \mathrm{m}^{-2}$ day $^{-1}$ (Caron, 2009).

Thus the objective of the present study was to assess the quality of mini tomato harvested at two ripeness stages and stored in three types of packaging.

\section{MATERIAL AND METHODS}

Sweet Grape cultivar mini tomatoes were harvested in a commercial production area located in Mogi Mirim (2226'0”'S; 4657'0”W), São Paulo state, Brazil, at two ripeness stages called light red and red (USDA, 1991). The fruits were transported in a nonrefrigerated vehicle to the post-harvest laboratory of the Escola Superior de Agricultura Luiz de Queiroz. Later they were selected for presence of damage and cleaned in a sodium hypochlorite solution $(200 \mathrm{ppm})$. Fruits with 60 to $90 \%$ of the peel with red coloring were considered for the light red ripeness stage. For the red ripeness stage, fruits were considered with more than $90 \%$ of the peel with red coloring, according to the USDA classification norms for tomato coloring (USDA, 1991).

The treatments consisted of three types of packaging (PEBD $30 \mu$, perforated PET and Vegetal Pack 18 $\mu)$ and two ripeness stages (light red and red). The fruits were packed on 180 g capacity $16 \times 16 \times 4 \mathrm{~cm}$ perforated PET trays. The Vegetable Pack plastic film was wrapped round the whole tray and sealed using an Everest ${ }^{\circledR}$ "Porta Película". The PEBD film plastic bag covered the whole tray and was sealed using an Everest ${ }^{\circledR}$ Termo Plástico welder the same size as the tray. Mini tomatoes placed only on a tray with a perforated PET lid were considered the control.

Physical and chemical analyses were carried out (soluble solid content, ascorbic acid, titratable total acidity, peel coloring, mass loss and lycopene contents). Shortly after closing the packaging the initial mass and the gas composition $\left(\mathrm{O}_{2}, \mathrm{CO}_{2}\right.$ and ethylene) were determined inside the packaging. The treatments were kept at $20 \pm 21^{\circ} \mathrm{C}$ for 20 days. Physical and chemical assessments were made every five days, except for the lycopene content that was measured on the first and last days of storage. The gas composition was assessed on the first and second day and then every five days.

For the destructive analyses, 10 whole fruits from each replication were ground using a Mixer and a homogeneous mass was obtained.

A complete randomized experimental design was used in a factorial scheme, with split plots in time with four replications consisting of 10 fruits each. The factors consisted of five assessment times, three types of packaging and two fruit ripeness stages.

Monitoring gas composition inside the packaging $\left(\mathrm{O}_{2}, \mathrm{CO}_{2}\right.$ and ethylene $)$

Carbon dioxide and oxygen evolution: samples of air from the free space in the packages were collected using a PBI Dansensor gas analyzer, model Check Mate that removed approximately $2 \mathrm{~mL}$ gas through silicone scepters fixed in the packaging. The results were expressed in percentages of $\mathrm{O}_{2}, \mathrm{CO}_{2}$ and ethylene.

Ethylene evolution: $1 \mathrm{~mL}$ samples of air were removed from the free space in the package with a Hamilton $2.5 \mathrm{~mL}$ Gastight syringe and injected in a gas chromatographer (Thermofinnigan, model GC Trace 2000), with a flame ionization detector (FID), using a "Propak N" column. The drag gas was hydrogen with a $30 \mathrm{~mL}$ minute ${ }^{-1}$ flow. The temperatures maintained in the apparatus were $80^{\circ} \mathrm{C}$ for the column, $100^{\circ} \mathrm{C}$ for the injector, $250^{\circ} \mathrm{C}$ for the detector and $350^{\circ} \mathrm{C}$ for the metanador. To establish the standard curve, aliquots 
of $1 \mathrm{~mL}$ of the 0.58 and $1.94 \mathrm{ppm}$ ethylene standards were injected in the gas chromatographer. The ethylene evolution was expressed in ppm.

Peel coloring - two readings were made on the equatorial region of each fruit with a Minolta colorimeter, model cr-300, using the $\mathrm{L}^{*} \mathrm{a}^{*} \mathrm{~b}^{*}$ system. The results were expressed by the $\mathrm{a}^{*} / \mathrm{b}^{*}$ ratio that designates the development index of the red color in tomatoes.

Lycopene - it was determined following methodology described by Sadler et al. (1990). One gram pulp was weighed from each replication in a $250 \mathrm{~mL}$ Erlenmeyer already wrapped in aluminum foil, and homogenized in a mixture of $50 \mathrm{~mL}$ hexane, $12.5 \mathrm{~mL}$ ethanol and $12.5 \mathrm{~mL}$ acetone at the proportion of $2: 1: 1, \mathrm{v}: \mathrm{v}: \mathrm{v}$. Shortly after mixing, the samples were centrifuged $30 \mathrm{~min}$ and then transferred to a separation funnel to which was added $10 \mathrm{~mL}$ distilled water. The solution was separated in polar and apolar fractions. The apolar fraction, with pigment, was measured by reading the hexane solution absorbency at $420 \mathrm{~nm}$, using the hexane as standard. The results were expressed in milligrams of lycopene per $100 \mathrm{~g}$ pulp.

Soluble solid content - a sample of the pulp from each replication was placed in a digital refractometer (Atago PR-101), with automatic temperature correction to $20^{\circ} \mathrm{C}$. The results were expressed in percentage.

Titratable acidity - $10 \mathrm{~g}$ of pulp from each replication were weighed and placed in $90 \mathrm{~mL}$ distilled water. The potentiometric titration was detected with sodium hydroxide $0.1 \mathrm{~mol} \mathrm{~L}^{-1}$ to $\mathrm{pH}$ 8.10. The calculations were made according to Carvalho et al. (1990) and the results expressed in percentage of citric acid in the pulp.

Soluble solids/acidity ratio: obtained by the ratio between the percentage of soluble solids and acidity.

Mass loss - calculated by the difference between the initial mass and the mass at the time of assessment, using semi-analytical scales, and the

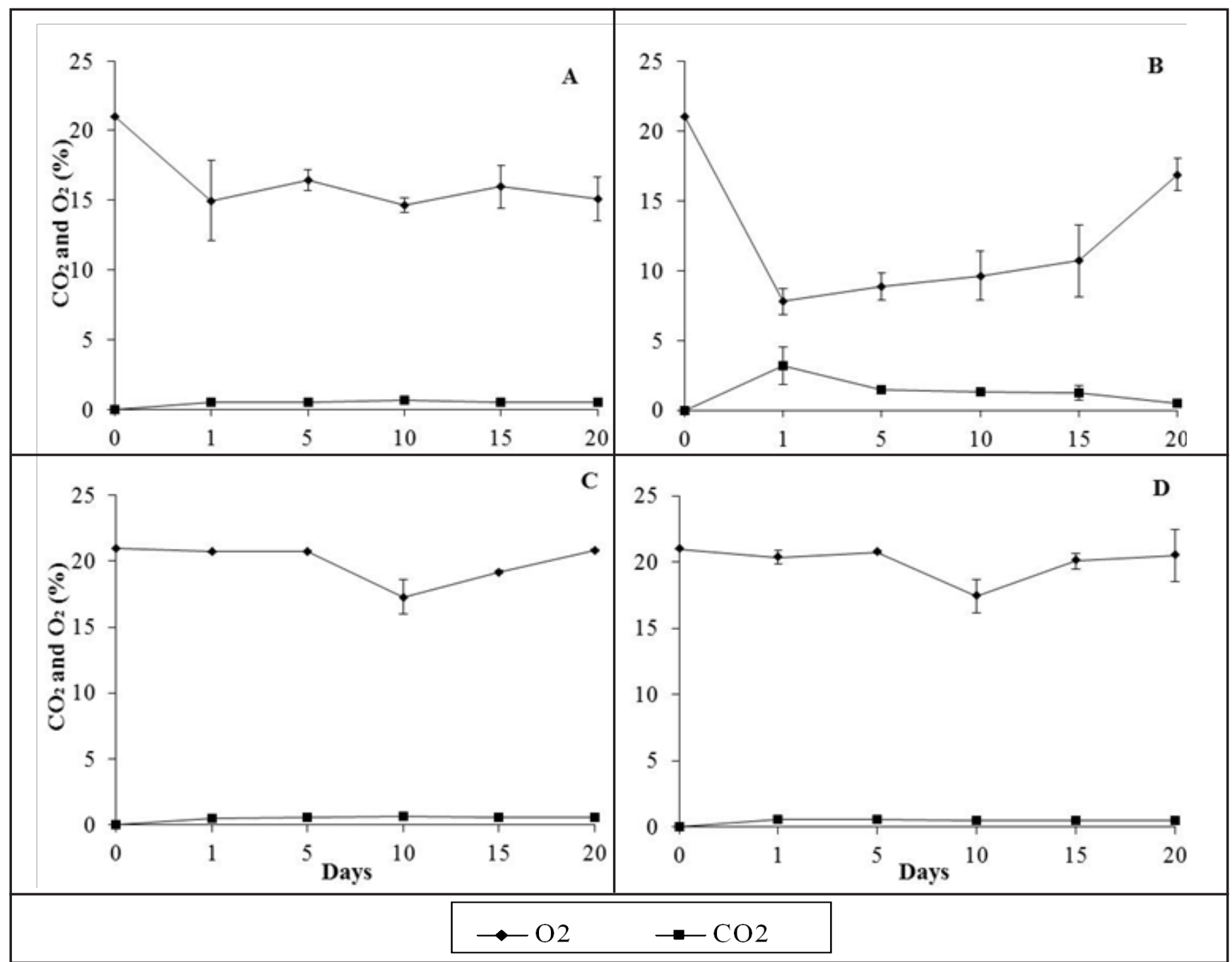

Figure 1. Gaseous composition inside the package with small tomatoes during storage at $20 \pm 1^{\circ} \mathrm{C}$ and $85 \pm 5 \%$ RH. (A) PEDB and red stage; (B) PEDB and light red stage; (C) Vegetal Pack and red stage; (D) Vegetal Pack and light red stage. Vertical bars represent the standard deviation [composição gasosa no interior das embalagens com mini tomates ao longo do armazenamento a $20 \pm 1^{\circ} \mathrm{C}$ e $85 \pm 5 \%$ de UR. (A) PEBD e estádio vermelho; (B) PEBD e estádio vermelho claro; (C) Vegetal Pack e estádio vermelho; (D) Vegetal Pack e estádio vermelho claro. Barras verticais representam o desvio padrão da média]. Piracicaba, ESALQ, 2010. 
results were expressed in percentage of initial mass.

Ascorbic acid content - it was determined according to methodology by Carvalho et al. (1990) based on reduction of the 2.6-dichlorophenolindolphenolsodium (DCFI) indicator by ascorbic acid. Five gram of pulp were weighed from each replication and placed in an Erlenmeyer flask containing $25 \mathrm{~mL}$ $1 \%$ oxalic acid solution. The titratable acidity was assessed with DCFI until a persistent pink coloring was obtained for 15 seconds. The results were expressed in milligrams of ascorbic acid per hundred grams pulp.

The data were submitted to the Hartley test $(p<0.05)$ to verify the homogeneity of variance among the treatments. Then analysis of variance was carried out by the $F$ test $(p<0.05$ and $\mathrm{p}<0.01$ ). According to the significance, the means of the qualitative data were compared by the Tukey test $(p<0.05)$ and the means of the quantitative data were submitted to polynomial regression analysis $(\mathrm{p}<0.05)$.

\section{RESULTS AND DISCUSSION}

Gas composition - The oxygen concentration decreased inside the PEBD film and Vegetable Pack packaging during the 20 days of storage at $20^{\circ} \mathrm{C}$. The PEBD film packaging had a more accentuated reduction of $\mathrm{O}_{2}$ from 21 to less than $10 \%$, and the carbon dioxide concentrations increased more, from 0.03 to $0.80 \%$, than the other

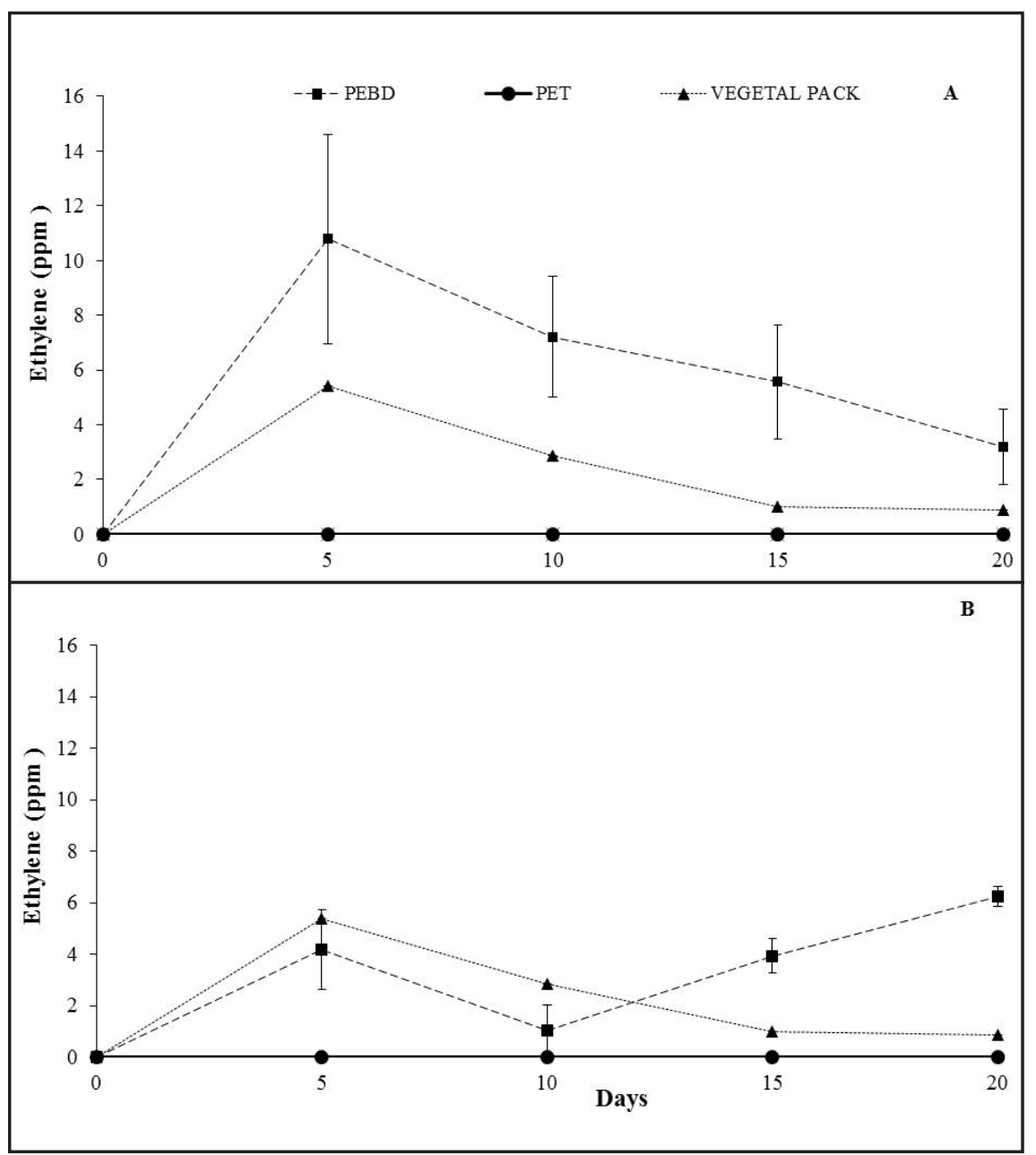

Figure 2. Accumulation of ethylene (ppm) inside the package with small tomatoes during storage at $20 \pm 1^{\circ} \mathrm{C}$ and $85 \pm 5 \%$ RH. (A) light red stage; (B) red stage. Vertical bars represent the standard deviation [acúmulo de etileno (ppm) no interior das embalagens com mini tomates durante o armazenamento a $20 \pm 1^{\circ} \mathrm{C}$ e $85 \pm 5 \%$ de UR. (A) estádio vermelho claro; (B) estádio vermelho. Barras verticais representam o desvio padrão da média]. Piracicaba, ESALQ, 2010.

packaging (Figure 1A and B).

The $30 \mu$ PEBD film resulted in lower oxygen concentrations inside the packaging after two days at $20^{\circ} \mathrm{C}$ with fruits at the light red stage compared to those with fruits at the red stage (Figure 1A and B). The Vegetable Pack film resulted in few alterations in the gas composition inside the packaging regardless of the fruit ripeness stage (Figures 1C and D) because oxygen decreased from 21 to $17 \%$ only at 10 days storage. The gas composition inside the perforated PET packaging (control) was the same as the environment $(21 \%$ oxygen and $0.03 \%$ carbon dioxide) during the 20 days at $20^{\circ} \mathrm{C}$ (data not shown).

The gas concentration resulting from using PEBD film (10\% oxygen and $0.8 \%$ carbon dioxide) for 20 days was justifiable because it presented lower permeability rates to carbon dioxide and oxygen than the other packaging types (Vegetable Pack and Perforated PET). This composition was similar to that reported by Akbudak et al. (2007) when they worked with heat treatment and used this film with $50 \mu$ in two cultivars of mini tomato. These authors observed that after 20 days the gas concentration inside the packaging was 10 to $15 \%$ oxygen and 1 to $2 \%$ carbon dioxide.

The highest ethylene values were obtained on the fifth day of storage and then decreased (Figures 2A and B). Carbon dioxide accumulation and reduced oxygen concentration inside the packaging probably inhibited ethylene production after this date. This performance was similar in all the treatments, except for the red tomatoes packed in PEBD film (Figure 2B). The greatest ethylene accumulation in the PEBD film packaging regardless of the ripeness stage was probably due to the lower permeability to gases of this film. The Vegetable Pack, however, presented smaller ethylene accumulation because it may have permitted greater permeability of the gases and further because the zeolite mineral, that has adsorption capability, is part of its composition. Studies using plastic films impregnated with zeolite have shown that the gas composition varies in function of 


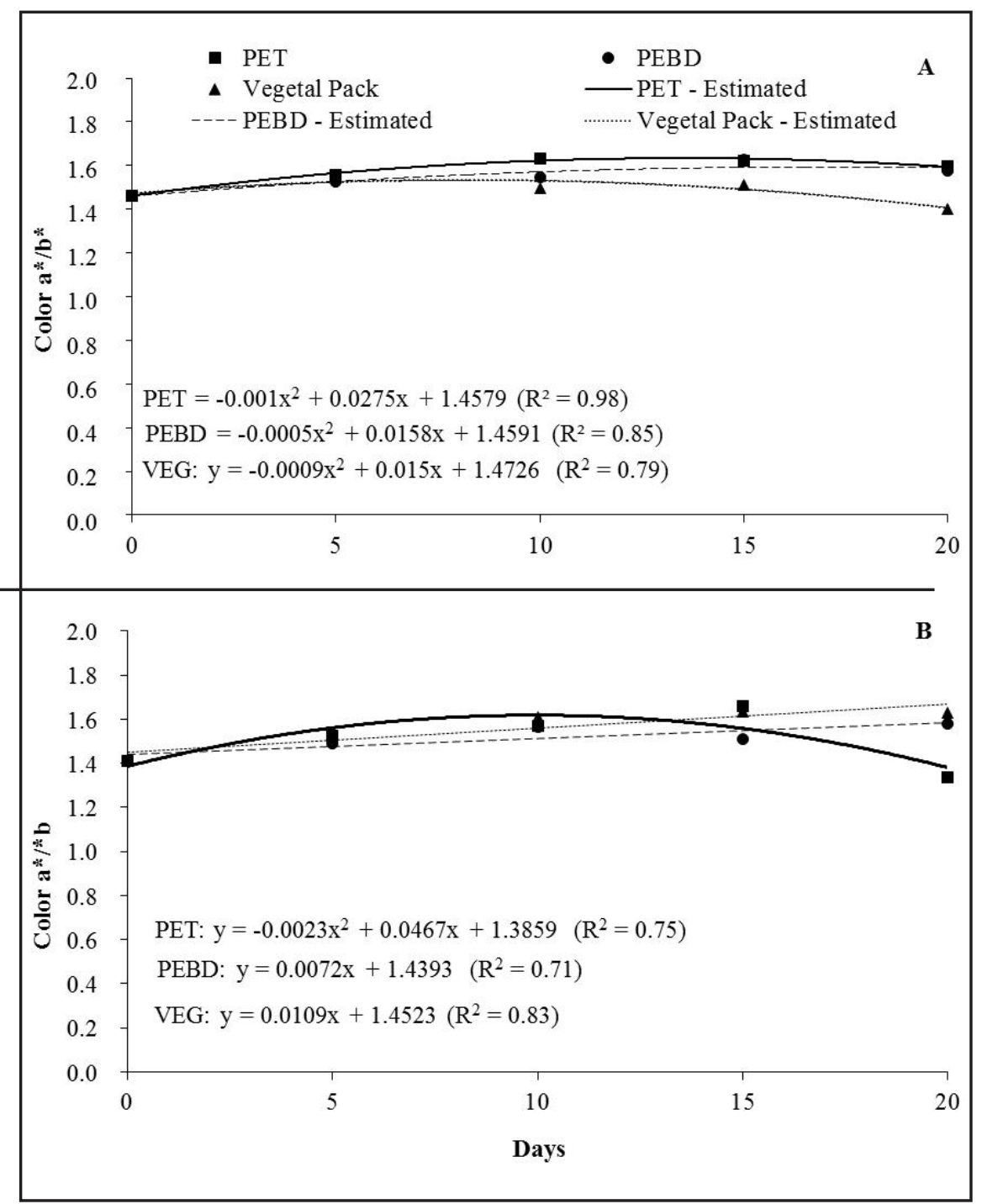

Figure 3. Evolution of peel color $\left(\mathrm{a}^{*} / \mathrm{b}^{*}\right)$ of small tomatoes of red stage (A) and of light red stage (B) packaged in plastic films during 20 days $20 \pm 1^{\circ} \mathrm{C}$ and $85 \pm 5 \%$ RH [evolução da coloração da casca $\left(\mathrm{a}^{*} / \mathrm{b}^{*}\right)$ dos mini tomates de estádio vermelho $(\mathrm{A})$ e de estádio vermelho claro (B) acondicionados em filmes plásticos durante 20 dias a $20 \pm 1^{\circ} \mathrm{C}$ e $85 \pm 5 \%$ de UR]. Piracicaba, ESALQ, 2010.

this mineral inside the packaging and therefore the respiratory rate of the fruit (Huang et al., 2013). The type and quantity of this mineral in the plastic film has also been shown to interfere in ethylene absorption (Patdhanagula et al., 2010).

The difference in ethylene concentration among the ripeness stages in the PEBD film packaging may have been related to the different physiology of each stage. The fruit harvesting process generates stress and mechanical damage that results in cell signaling with the response of greater ethylene production (Ayub et al., 1995) that is accentuated when the fruits are
(Figure 3).

The red stage fruits were influenced by the type of packaging. When stored in Vegetable Pack, the $a^{*} / b^{*}$ ratio increased for peel coloring until the eighth day, but then decreased. Differently, fruits in the Perforated PET and PEBD film packaging expressed gradual increase in the $\mathrm{a}^{*} / \mathrm{b}^{*}$ ratio over the 20 days storage (Figure $3 \mathrm{~A}$ ).

Fruits at the light red stage placed in PEBD film and Vegetable Pack presented a linear increase in the red coloring over time, but when they were placed in the Perforated PET packaging (control) the $\mathrm{a}^{*} / \mathrm{b} *$ ratio decreased after 10 days at $21^{\circ} \mathrm{C}$ (Figure 3B).

It can be inferred that the fruits stored in the PEBD and Vegetable Pack film were better preserved because the modified atmosphere resulted in reduced net metabolic activity of the fruits and consequently in the attributes that characterize their ripeness. In studies using modified atmosphere for tomato storage, PEBD film also delayed the development of the red coloring longer than the biodegradable packaging (Kantola \& Hélen, 2001; Suparlan \& Itoh, 2003).

Lycopene content - There was interaction among the types of packaging, fruit ripeness stages and storage time for the lycopene content. At 20 days storage at $20-21^{\circ} \mathrm{C}$ the lycopene contents were higher in the light red fruit stored in the three types of packaging compared to the contents determined shortly after harvest. Furthermore, the fruits of this stage, when placed in the Perforated PET packaging, presented greater increase in the lycopene contents than the other treatments $(\mathrm{p}<0.05)$, ending at 20 days with $18.58 \mathrm{mg}$ $100 \mathrm{~g}^{-1}$ (Table 1). This fact did not occur for the red fruits whose contents were maintained without significant difference throughout the storage period.

The lycopene content of the tomatoes at the red stage was greater in the PEBD film than in the Vegetable Pack, at 20 days storage. The lycopene content was greatest in the light red tomatoes in the Perforated PET packaging (Table 1).

Lycopene content in tomatoes 


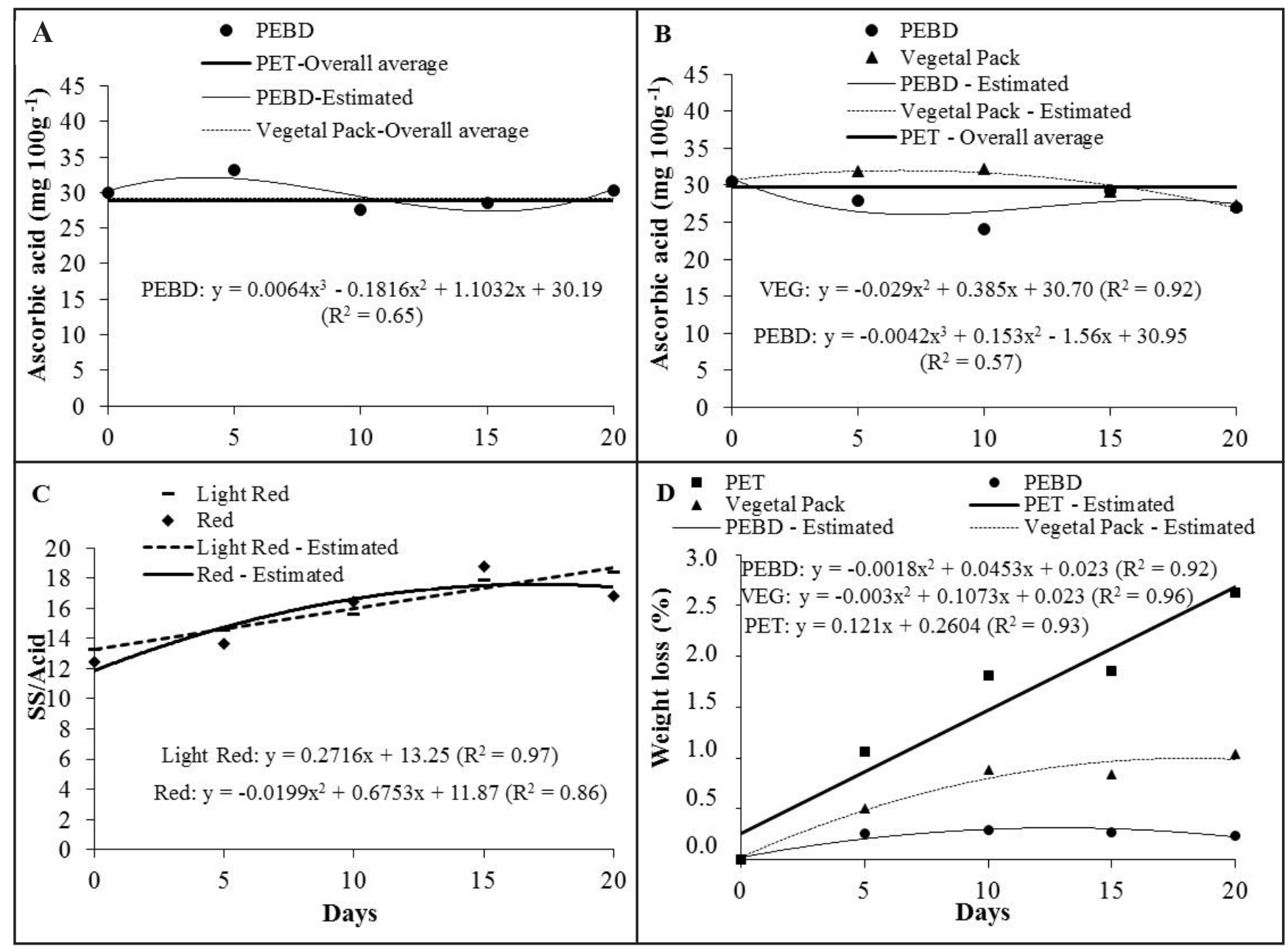

Figure 4. Evolution of ascorbic acid in small red tomatoes (A) and red light tomatoes (B) ratio of soluble solids and acidity (C) and weight loss (D) during storage at $20 \pm 1^{\circ} \mathrm{C}$ and $85 \pm 5 \% \mathrm{RH}$ [evolução do teor de ácido ascórbico em mini tomates vermelhos (A) e vermelho claros (B); relação de sólidos solúveis e acidez titulável (C) e perda de massa (D) durante o armazenamento a $20 \pm 1^{\circ} \mathrm{C}$ e $85 \pm 5 \%$ de UR]. Piracicaba, ESALQ, 2010.

depends on the ripeness stage and the development conditions of the fruits (Javanmardi \& Kubota, 2006). Furthermore, modification in the atmosphere can interfere in the synthesis of this pigment because it reduces the fruit metabolic activities resulting in lower ethylene production and decreased physiological changes (Fonseca et al., 2002). As the tomato ripening process is associated with increase in lycopene content (Javanmardi \& Kubota, 2006), delay in this process can result in lower contents of this compound, as reported by Siripatrawan \& Assatarakul (2009) when they used $32 \mu$ commercial film associated with methyl jasmonate to store unripe tomatoes.

In the mini tomatoes studied 8 to 18 mg $100 \mathrm{~g}^{-1}$ lycopene were found during storage, equivalent to the contents determined by Pernice et al. (2010), Siripatrawan \& Assatarakul (2009) in cherry tomatoes, with contents from 9 to $14 \mathrm{mg} 100 \mathrm{~g}^{-1}$ after 20 days storage.

Soluble solids and acidity ratio The red fruit presented second-degree polynomial performance during storage with the highest soluble solids and acidity ratio at 17 days. The light red fruits resulted in linear regression with increase in this ratio up to 20 days storage (Figure 4C). These results corroborate Guillén et al. (2006), who demonstrated differences among the tomato ripeness stages during storage for the soluble solids and acidity ratio. However, in a study carried out with "Cronos" tomatoes, the soluble solids and acidity contents did not differ significantly for storage time and nor for the partially ripe and ripe ripeness stages (Brackman et al., 2007).

As the acidity and soluble solids contents directly influence fruit flavor, these results showed that tomatoes harvested at the light red stage, regardless of the packaging, showed increase in terms of flavor, while flavor started to decrease on the $17^{\text {th }}$ day of storage at $22^{\circ} \mathrm{C}$ those harvested at the red stage.

Mass loss (\%) - The fruits stored in the three types of packaging, regardless of the ripeness stage, presented mass loss over time. However, when in Perforated PET, the fruits lost about 3\% fresh matter by the end of storage. When placed in Vegetable Pack and PEBD film, however, they lost $1 \%$ and $0.24 \%$, respectively, by the end of the 20 days (Figure 4 D). 
Table 1. Effect of packaging and storage time ( 0 and 20 days) in the lycopene content ( $\mathrm{mg}$ $100 \mathrm{~g}^{-1}$ ) in small tomatoes stored at $20 \pm 1^{\circ} \mathrm{C}$ and $85 \pm 5 \% \mathrm{RH}$ [efeito das embalagens e do

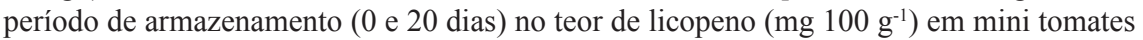
armazenados a $20 \pm 1^{\circ} \mathrm{C}$ e $85 \pm 5 \%$ de UR]. Piracicaba, ESALQ, $2010^{1}$.

\begin{tabular}{|c|c|c|}
\hline \multirow{2}{*}{ Package } & \multicolumn{2}{|c|}{ Light red stage } \\
\hline & Day 0 & Day 20 \\
\hline PET (perforated) & $8.04 \pm 1.20 \mathrm{~B} \mathrm{a}$ & $18.58 \pm 0.56 \mathrm{~A} \mathrm{a}$ \\
\hline PEBD & $8.04 \pm 1.20 \mathrm{~B} \mathrm{a}$ & $14.72 \pm 2.21 \mathrm{~A} \mathrm{~b}$ \\
\hline \multirow[t]{3}{*}{ Vegetal Pack } & $8.04 \pm 1.20 \mathrm{~B} \mathrm{a}$ & $16.12 \pm 2.15 \mathrm{~A} \mathrm{~b}$ \\
\hline & \multicolumn{2}{|c|}{ Red stage } \\
\hline & Day 0 & Day 20 \\
\hline PET (perforated) & $14.32 \pm 1.89 \mathrm{~A} \mathrm{a}$ & $15.66 \pm 1.15 \mathrm{~A} \mathrm{ab}$ \\
\hline PEBD & $14.32 \pm 1.89 \mathrm{~A} \mathrm{a}$ & $16.42 \pm 1.39 \mathrm{~A} \mathrm{a}$ \\
\hline Vegetal Pack & $14.32 \pm 1.89 \mathrm{~A} \mathrm{a}$ & $13.82 \pm 2.20 \mathrm{~A} \mathrm{~b}$ \\
\hline
\end{tabular}

Of the two films the PEBD film presented greater fruit mass conservation over time. In other studies, the greater conservation of mass was also obtained in 'Chiranjeevi' cultivar tomatoes when stored in PEBD and non-perforated PET packaging (Yadav et al., 2009). The same occurred for cherry tomatoes when stored in $50 \mu$ PEBD film (Akbudak et al., 2007). This fact was due to the greater accumulation of water vapor inside the PEBD film packaging that helps maintain fruit turgidity (Akbudak et al., 2007).

Ascorbic acid content - There was interaction between the fruit ripeness stages, packaging type and storage time for ascorbic acid content (Figure $4 \mathrm{~A}$ and $\mathrm{B})$. For the red fruits, stored in PEBD film packaging, the ascorbic acid content presented third-degree polynomial performance (Figure 4A). However, for the fruits in Perforated PET and Vegetable Pack packaging, the ascorbic acid content remained constant throughout storage, with a general mean of 28.87 and $29.18 \mathrm{mg} 100 \mathrm{~g} \mathrm{~g}^{-1}$, respectively (Figure 4A).

The ascorbic acid content in light red fruits in Vegetable Pack decreased after the $10^{\text {th }}$ day of storage. However, when packed in Perforated PET they remained with contents of $29.77 \mathrm{mg}$ $100 \mathrm{~g}^{-1}$ throughout the storage period and in PEBD film they presented minimum and maximum values).

The Sweet Grape tomatoes harvested at two ripeness stages performed differently in the post-harvest. The fruits harvested at the light red stage imply an increase in the lycopene content, the red index and soluble solids/acidity ratio during the 20 days. This showed that tomatoes can be harvested before they reach the red stage that allows a longer commercialization period.

The PEBD film altered the gas composition inside the packaging with mini tomato, so that the peel color was maintained. Furthermore, the barrier to water vapor resulted in a smaller fresh mass loss, keeping the fruits turgid for longer so that this film is the most indicated for maintaining these attributes. The Vegetable Pack film, however, presented no advantage compared to the Perforated PET packaging (control).

\section{REFERENCES} $(\mathrm{p}<0.05)$ for the fruits at the light red stage, around $5 \mathrm{mg} 100 \mathrm{~g}^{-1}$ at the end of storage, when placed in the PEBD film and Vegetable Pack packaging. This may have occurred as a result of a more accelerated metabolism in these fruits due to stress from early harvest and the lower oxygen concentrations resulting from the modified atmosphere. Studies on the performance of ascorbic acid synthesis and oxidation in tomatoes have shown that stress due to low oxygen levels can reduce synthesis and also oxidation, because the specific genes related to these two processes are deactivated or inhibited for a certain period (Loannidi et al., 2009). This also explains the constant ascorbic acid contents during storage for the fruits packed only in Perforated PET.

The ascorbic acid content in the tomato fruit varies according to the period of the year, cultivar, lightness fertilization and substrate (Sampaio \& Fontes, 1998). Holcman (2009) reported ascorbic acid contents from 19 to $24 \mathrm{mg}$ $100 \mathrm{~g}^{-1}$ for the Sweet Grape and Sweet Million tomato cultivars, respectively, cultivated in a protected environment. These contents are similar to those obtained for the mini tomato in the present study (23 and $35 \mathrm{mg} 100 \mathrm{~g}^{-1}$,
AKBUDAK B; AKBUDAK N; SENIZ V; ERIS A. 2007. Sequential treatments of hotwater and modified atmosphere packaging in cherry tomatoes. Journal of Food Quality 30: 896-910.

AKBUDAK B; AKBUDAK N; SENIZ V; ERIS A. 2012. Effect of pre-harvest harpin and modified atmosphere packaging on quality of cherry tomato cultivars "Alona" and "Cluster". British Food Journal 114: 180-196.

AYUB R; GUIS M; BEN AMOR M; GILLOT L; ROUSTAN J; LATCHÉ A; BOUZAYEN M; PECH JC. 1995. Expression of ACC oxydase antisense gene in melon. Plant Physiology Science 108: 150.

BECKLES DM. 2012. Factors affecting the postharvest soluble solids and sugar content of tomato (Solanum lycopersicum L.) fruit. Postharvest Biology and Technology 63: 129-140.

BRACKMANN A; STEFFENS CA; ANDRIOLO JL; PINTO JAV. 2007. Armazenamento de tomate cultivar "Cronus" em função do estádio de maturação e da temperatura. Ciência Rural 37: 1295-1300.

CARON VC. 2009. Conservação refrigerada de lima ácida 'Tahiti' em combinação com atmosfera modificada, ácido giberélico e permanganato de potássio. Piracicaba: USPESALQ, 97p. (Dissertação mestrado).

CARVALHO CRL; CARVALHO PRN; MANTOVANI DMB; MORAES RM. 1990. Análise química de alimentos. Campinas: ITAL, 121p.

CARVALHO W; FONSECA MEN; SILVA HR; BOITEUX LS; GIORDANO LB. 2005. Estimativa indireta de teores de licopeno em 
frutos de genótipos de tomateiro via análise colorimétrica. Horticultura Brasileira 23: 819-825.

CHAVES AL; ROMBALDI C; ARAUJO PJ; BALAGUÉ C; PECH JC; AYUB A. 1998. Ciclo de maturação e produção de etileno de tomates (lycopersicon esculentum, Mill.) transgênicos. Ciência e Tecnologia de Alimentos 18: 116-120.

DAY B. 2002. Industry guidelines for high oxygen MAP of fresh prepared produce. Acta Horticulturae 599: 81-90.

FONSECA SC; OLIVEIRA FAR; BRECHT JK. 2002. Modelling respiration rate of fresh fruits and vegetables for modified atmosphere packaging: A review. Journal of Food Engineering 52: 99-119.

GORRIS LGM; PEPPELENBOS HW. 1992. Modified atmosphere and vacuum packaging to extend the shelf life of respiring food products. HortTechnology 2: 303-309.

GUILLÉN F; CASTILLO AS; ZAPATA PJ; MARTÍNEZ-ROMERO AD; VALERO AD; SERRANO AM. 2006. Efficacy of 1-MCP treatment in tomato fruit 2. Effect of cultivar and ripening stage at harvest. Postharvest Biology and Technology 42: 235-242.

HOLCMAN E. 2009. Microclima e produção de tomate tipo cereja em ambientes protegidos com diferentes coberturas plásticas Piracicaba: USPESALQ. 12p. (Dissertação mestrado).

HUANG Z; GUO YH; ZHANG TM; ZHANG XH; GUOLY.2013. Fabrication and characterizations of zeolite beta-filled polyethylene composite films. Packaging Technology and Science 26: $1-10$.

IBGE. 2008-2009. Pesquisa de orçamentos familiares - Aquisição alimentar domiciliar per capita - Brasil e grandes regiões. Disponível em: <www.ibge.gov.br/home/...aquisicao/ pof20082009_aquisicao.pdf>. Acesso em: 01/09/2012.

IOANNIDI E; KALAMAKI MS; ENGINEER C; PATERAKI I; ALEXANDROU D; MELLIDOU I; GIOVANNONNI J; KANELLIS AK. 2009. Expression profiling of ascorbic acid-related genes during tomato fruit development and ripening and in response to stress conditions. Journal of Experimental Botany 60: 663-678.

JAVANMARDI J, KUBOTA C. 2006. Variation of lycopene, antioxidant activity, total soluble solids and weight loss of tomato during postharvest storage. Postharvest Biology and Technology 41: 151-155.

JUNQUEIRA AH; PEETZ MS; ONODA SM. 2011. Um modelo de inovação na gestão da cadeia de produção e distribuição de hortaliças diferenciadas no Brasil. ESPM, Central de cases. Disponível em: http://www.organicsnet. com.br/wp-content/uploads/sweet_grape.pdf

KADER AA; ZAGORY D; KERBEL EL. 1989. Modified atmosphere packaging of fruits and vegetable. Critical Reviews in Food Science and Nutrition 28: 1-30.

KADER AA. 2008. Perspective: flavor quality of fruits and vegetables. Journal of the Science of Food and Agriculture 88: 1863-1868.

KANTOLA M; HELÉN H. 2001. Quality changes in organic tomatoes packaged in biodegradable plastic films. Journal of Food Quality 24: 167-176.

MOSCA JL; MUNOL MM; VIEITES RL. 1999. Atmosfera modificada na pós-colheita de frutas e hortaliças. Botucatu: FEPAF, 28 p.

MOURA ML; SARGENT SA; OLIVEIRA RF. 1999. Efeito da atmosfera controlada na conservação de tomates colhidos em estádio intermediário de maturidade. Scientia Agrícola 56: 135-142.

PATDHANAGULA N; SRITHANRATANAA T, RANGSRIWATANANONB K; HENGRASMEEAS. 2010. Ethylene adsorption on cationic surfactant modified zeolite NaY. Microporous and Mesoporous Materials 131: 97-102.

PERNICE R; PARISI M; GIORDANO I; PENTANGELOA; GRAZIANI G; GALLO M; FOGLIANO V; RITIENIA. 2010. Antioxidants profile of small tomato fruits: effect of irrigation and industrial process. Scientia Horticulturae 126: 156-163.

PICHA DH. 1986. Effect of harvest maturity on the final fruit composition of cherry and large- fruited tomate cultivars. Journal of the American Society for Horticultural Science 111: 723-727.

RAFFO A; LEONARDI C; FOGLIANO V; AMBROSINO P; SALUCCI M; GENNARO L; BUGIANESI R; GIUFFRIDAF; QUAGLIA G. 2002. Nutritional value of cherry tomatoes (Lycopersicon esculentum Cv. Naomi F1) harvested at different ripening stages. Journal of Agricultural and Food Chemistry 50: 65506556.

SABIR FK; AGAR T. 2011. Effects of 1-methylcyclopropene and modified atmosphere packing on postharvest life and quality in tomatoes. Journal of Food Quality 34: 111-118.

SADLER G; DAVIS J; DEZMAN D. 1990. Rapid extraction of lycopene and $\beta$-carotene from reconstituted tomato paste and pink grapefruits homogenates. Journal of Food Science 55: 1460-1461.

SAMPAIO RA; FONTES PCR. 1998. Qualidade de frutos de tomateiro fertirrigado com potássio no solo coberto com polietileno preto. Horticultura Brasileira 16: 136-139.

SIRIPATRAWAN U; ASSATARAKUL K. 2009. Methyl jasmonate coupled with modified atmosphere packaging to extend shelf life of tomato (Lycopersicon esculentum Mill.) during cold storage. International Journal of Food Science and Technology 44: 1065-1071.

SUPARLAN B; ITOH K. 2003. Combined effects os hot water treatment (HWT) and modified atmosphere packaging (MAP) on quality of tomatoes. Packaging Technology and Science 16: 171-178.

USDA. 1991. Standard for Grades of Fresh Tomatoes. United States Department of Agriculture, Agricultural Marketing Service, p.13.

VANNDY M.; BUNTONG B; ACEDO A; WEINBERGER K. 2008. Modified atmosphere packaging to improve shelf life of tomato fruit in Cambodia. Acta Horticulturae 804: 453-457.

YADAV RK; SANWAL SK; SINGH PK; JURI B. 2009. Effect of pretreatments and packaging of tomato in LDPE and PET films on the storage-life. Journal of Food Science and Technologgy.46: 139-141. 